\section{Further Evidence of a Genetic Basis for Varied Levels of Injury to Sweet Corn Hybrids from Cytochrome P450-metabolized Herbicides Applied Postemergence}

\author{
Martin M. Williams II ${ }^{\mathbf{1}}$ and Loyd M. Wax \\ U.S. Department of Agriculture, Agricultural Research Service, Invasive \\ Weed Management Research, University of Illinois, 1102 South Goodwin \\ Avenue, Urbana, IL 61801 \\ Jerald K. Pataky and Michael D. Meyer \\ Department of Crop Sciences, University of Illinois, Urbana, IL 61801
}

Additional index words. benl gene, carfentrazone, foramsulfuron, herbicide selectivity, herbicide sensitivity, herbicide tolerance, halosulfuron, mesotrione, nicosulfuron, $n s f 1$ gene, tembotrione, Zea mays

\begin{abstract}
Over the last two decades, sweet corn injury from postemergence herbicides has resulted in routine screening of combinations of new and existing hybrids and herbicides. Sensitivity of sweet corn to several cytochrome P450-metabolized herbicides is simply inherited and has a common genetic basis, a single $\mathbf{P 4 5 0}$ locus that may account for a large amount of the variation in sweet corn injury commonly observed among screening trials. Using data from 13 hybrid-herbicide screening trials, the objective of this work was to determine the extent to which injury from P450-metabolized herbicides was associated with the genotypes of hybrids at a locus affecting herbicide sensitivity. Of the 703 hybrids evaluated in the University of Illinois sweet corn hybrid nurseries from 2002 to 2007 , previous work showed that a total of 104,70 , and nine of the hybrids were known to be homozygous-tolerant, heterozygous, or homozygous-sensitive, respectively, for an allele affecting herbicide response. Nurseries from 2002 to 2007 included six trials with mesotrione, three trials with nicosulfuron, and one trial each with foramsulfuron, tembotrione, halosulfuron, and carfentrazone. When means of hybrids in genotypic classes were compared, homozygous-sensitive hybrids were consistently injured more severely than homozygous-tolerant and heterozygous hybrids. When environmental conditions favored crop injury, heterozygous hybrids had an intermediate response that was closer to homozygous-tolerant hybrids than homozygous-sensitive hybrids. These data are further evidence that the probability of injury from several P450-metabolized herbicides, including mesotrione, nicosulfuron, foramsulfuron, tembotrione, halosulfuron, and carfentrazone, is highest in homozygous-sensitive hybrids and least in homozygous-tolerant hybrids and that variability of responses among sweet corn hybrids to these P450-metabolized herbicides can be explained largely by the genotype of a hybrid at a single locus.
\end{abstract}

Because certain sweet corn hybrids are sensitive to postemergence herbicides, new hybrids frequently are screened for responses to existing herbicides, and new herbicides are

routinely tested for potential injury to existing hybrids (e.g., Diebold et al., 2003; Morton and Harvey, 1992; Stall and Bewick, 1992; Williams and Pataky, 2008). Although

Received for publication 30 Apr. 2008. Accepted for publication 24 July 2008.

A portion of this research was supported by the Midwest Food Processors Association.

We greatly appreciate the cooperation of various companies that contributed seed for the UI sweet corn hybrid nurseries, including Abbot \& Cobb, Inc., Feasterville, PA; Centest Inc., Harvard, IL; Crookham Company, Caldwell, ID; Del Monte USA, Rochelle, IL; General Mills Green Giant Agricultural Research, LeSueur, MN; Harris Moran Seed Company, Modesto, CA; Illinois Foundation Seeds Inc., Champaign, IL; Mesa Maize, Olathe, CO; Syngents Seeds Inc. Rogers Brands, Boise, ID; Sakata Seed USA, Morgan Hills, CA; Seminis Inc., Oxnard, CA; and Snowy River Seeds, Orbost, Australia. We appreciate the cooperation of Christy Sprague with the 2003 trial and Bryan Warsaw, Jim Moody, Yim So, John Frihauf, and Ryan Hasty for their technical assistance.

Mention of a trademark, proprietary product, or vendor does not constitute a guarantee or warranty of the product by the U.S. Department of Agriculture and does not imply its approval to the exclusion of other products or vendors that also may be suitable.

${ }^{1}$ To whom reprint requests should be addressed; e-mail Martin.Williams@ars.usda.gov this type of screening identifies hybrids that may be injured from postemergence herbicides, a more comprehensive understanding of the genetic basis of herbicide sensitivity in sweet corn offers a mechanism by which this problem can be addressed and possibly solved by elimination of alleles that render sweet corn sensitive.

A sensitive or tolerant response of sweet corn to several cytochrome P450-metabolized herbicides is a simply inherited trait. Alleles at a single cytochrome P450 (CYP) locus (or a group of very closely linked loci) on the short arm of chromosome $5 \mathrm{~S}$ condition response of corn to multiple, P450-metabolized herbicides, including: bentazon, carfentrazone, dicamba plus diflufenzopyr, foramsulfuron, imazethapyr, mesotrione, nicosulfuron, primisulfuron, rimsulfuron, and tembotrione (Barrett et al., 1997; Nordby et al., 2008; Pataky et al., 2006b; Williams and Pataky, 2008). A single gene conditioning sensitivity to nicosulfuron was identified from a field corn inbred W703a and designated as $n s f 1$ (Kang, 1993). A single gene conditioning cross-sensitivity to bentazon and nicosulfuron was identified in the field corn inbred GA209 and designated as ben1 (Barrett et al., 1997; Bradshaw et al., 1994; Fleming et al., 1988). An allele at the Nsf1 locus on chromosome $5 \mathrm{~S}$ from a nicosulfuron-tolerant field corn inbred, B73, contained the highly conserved heme-binding sequence FxxGxxCxG found in most cytochrome $\mathrm{P} 450$ genes (Williams et al., 2006). Alleles in the field corn inbreds, GA209 and W703a, contained identical 392 base pair insertions in this gene sequence relative to B73. Thus, it appears that this insertion mutation results in a nonfunctional $\mathrm{P} 450$ allele resulting in herbicide sensitivity and that the $n s f l$ and benl genes are the same mutant of a CYP gene.

Cross-sensitivity to multiple P450metabolized herbicides also is simply inherited in the sweet corn inbred Cr1 (Nordby et al., 2008; Pataky et al., 2006b; Williams and Pataky, 2008). The allele (or closely linked alleles) in $\mathrm{Cr} 1$ that conditions the cross-sensitivity map to the same region of chromosome $5 \mathrm{~S}$ as the Nsf1/Ben1 locus and progeny from crosses of $\mathrm{Cr} 1$ with GA209 and W703a have homogeneous responses to nicosulfuron and mesotrione (Nordby et al., 2008). Thus, cross-sensitivity in $\mathrm{Cr} 1$ appears to be the result of the same insertion mutation as nsfl/benl, a similar mutation, or an allele at a very closely linked locus.

The common genetic basis for crosssensitivity to several P450-metabolized herbicides is prevalent in sweet corn grown in nearly every market in North America and throughout the world. Forty-five sweet corn hybrids and 29 sweet corn inbreds were either homozygous or heterozygous for an allele that is the same as or very closely linked to alleles in $\mathrm{Cr} 1$ that condition cross-sensitivity (Pataky, unpublished data). This group of hybrids and inbreds represents sweet corn germplasm from 12 different commercial 
breeding programs and includes sugary, sugary enhancer, and shrunken-2 endosperm mutants. Some of these hybrids were among a group of 149 sweet corn hybrids evaluated for responses to foramsulfuron, mesotrione, and nicosulfuron in 12 trials in six states (Bollman et al., 2005). Those 149 hybrids differed genotypically for the presence or absence of alleles affecting herbicide metabolism and phenotypically for their response to the three P450-metabolized herbicides (Pataky et al., 2008). When trial mean levels of injury were above minimal levels (e.g., $1 \%$ to $6 \%$ depending on the herbicide), response of the three genotypic classes of hybrids followed a consistent pattern. Homozygoussensitive hybrids were killed or severely injured. Heterozygous hybrids had intermediate responses that were more similar to homozygous-tolerant than homozygous-sensitive hybrids; however, injury to heterozygous hybrids was 1.5 to 2.3 times greater than injury to homozygous-tolerant hybrids. In another trial, homozygous-sensitive hybrids were killed by tembotrione plus the safener isoxadifen-ethyl applied at a standard use rate, whereas homozygous-tolerant and heterozygous hybrids were uninjured (Williams and Pataky, 2008).

Since 2002, 249 to 379 sweet corn hybrids were evaluated annually for responses to postemergence herbicides as part of the University of Illinois sweet corn hybrid nurseries (Pataky et al., 2002, 2003, 2004, 2005, 2006a, 2007). Hybrid responses to mesotrione were evaluated in each year. Other herbicides evaluated in at least 1 year included carfentrazone, foramsulfuron, halosulfuron, nicosulfuron, and tembotrione. Herbicide evaluations were added to the UI sweet corn hybrid nurseries at a time when little was known about the inheritance of herbicide sensitivity in sweet corn. Although these data have been used to report individual hybrid responses, further analysis would provide an independent test of the genetic basis for varied levels of injury to sweet corn from P450-metabolized herbicides. The objective was to determine the extent to which injury observed in these nurseries was associated with the genotypes of hybrids at a locus conditioning herbicide sensitivity.

\section{Materials and Methods}

Hybrid nurseries. Sweet corn hybrids were obtained from every major seed company with breeding programs in North America and included widely grown hybrids and precommercial hybrids in the final stages of development (Pataky et al., 2002, 2003, 2004, 2005, 2006a, 2007). Field experiments were conducted from 2002 to 2007 at the University of Illinois Crop Sciences Research and Education Center near Urbana, IL, on Flanagan silt loam (fine, smectitic, mesic Aquic Argiudoll) soils. Fields were cultivated and fertilized using practices typical to the region and planted from 13 May to 31 May. Early-season weeds were controlled with a preemergence application of $2.2 \mathrm{~kg} \cdot \mathrm{ha}^{-1}$ atrazine plus $1.8 \mathrm{~kg} \cdot \mathrm{ha}^{-1} S$-metolachlor.

A total of 13 experiments evaluating P450-metabolized herbicides were conducted from 2002 to 2007 testing six herbicides representing three herbicide modes of action (Table 1). Each experiment consisted of two to 10 replicates of 249 to 379 hybrids arranged in a randomized complete block design. An experimental unit was a single row with 12 to 18 plants. Commercial formulations of mesotrione, nicosulfuron, foramsulfuron, tembotrione, halosulfuron, and carfentrazone were applied at $1 \times$ or $2 \times$ the recommended use rates with standard adjuvants (Table 1). Herbicides were applied when sweet corn had four to six visible leaf collars, ranging from 14 June to 21 June, using backpack or tractor-mounted compressed-air sprayers delivering 130 to $187 \mathrm{~L} \cdot \mathrm{ha}^{-1}$ of water. Injury from herbicide application was observed primarily as chlorosis and bleaching (mesotrione and tembotrione), whole-plant stunting and necrosis (halosulfuron, foramsulfuron, and nicosulfuron), and leaf necrosis (carfentrazone). Hybrids were rated visually for percentage of injury once or twice at 7 to $21 \mathrm{~d}$ after treatment (DAT).

Genotypes of hybrids. Several of the hybrids evaluated in the sweet corn nurseries were previously assigned to genotypic classes at a locus conditioning herbicide sensitivity (Pataky et al., 2008; Pataky, unpublished data). Hybrids were classified as homozygous-tolerant, heterozygous, or homozygous-sensitive based on responses of $\mathrm{F}_{2}$ progeny and/or responses of progeny from testcrosses with $\mathrm{Cr} 1$ to foramsulfuron, mesotrione, and nicosulfuron. Plants sensitive to nicosulfuron or foramsulfuron usually were dead, whereas the apical meristem of plants sensitive to mesotrione was severely chlorotic or bleached. The number of sensitive and tolerant progeny was counted. Hybrids with all $\mathrm{F}_{2}$ and/or testcross progeny severely injured were classified as sensitive and homozygous for an allele conditioning herbicide sensitivity. Hybrids with uninjured progeny were classified as tolerant and homozygous for an allele conditioning herbicide tolerance. Hybrids with sensitive and tolerant progeny were tested by $\chi^{2}$ analysis for goodness of fit for segregation of tolerant:sensitive $F_{2}$ and testcross progeny in ratios that would be expected if a single dominant gene conditioned a tolerant phenotypic response (e.g., the $N s f 1$ allele). If segregation of progeny fit the expected ratios $(P>0.01)$, hybrids were classified as heterozygous for alleles conditioning tolerance and sensitivity.

Comparison of responses among genotypes. Means of injury of genotypic classes within each experiment were calculated from responses of hybrids with known genotypes. Mean levels of injury were compared among homozygous-sensitive, heterozygous, and homozygous-tolerant hybrids by multiple comparison tests (Fisher's $\mathrm{LSD}_{0.05}$ ) and also by $t$ tests among all three combinations of genotypic classes. When injury was rated at both 7 and 21 DAT within an experiment, data were analyzed separately by sampling time. Because mesotrione was evaluated in the nursery each year, distributions of hybrid response to mesotrione for each of the three genotypic classes were derived for data from all 6 years. Genotypic means of hybrid responses to mesotrione were tested as described.

\section{Results}

Based on injury responses to cytochrome P450-metabolized herbicides, a total of 104, 70, and nine hybrids were classified as homozygous-tolerant, heterozygous, and homozygous-sensitive, respectively (Table 2). In any single year, 26 to 72

Table 1. Details of herbicide applications in sweet corn hybrid nurseries, 2002 to 2007.

\begin{tabular}{|c|c|c|c|}
\hline Herbicide & Mode of action ${ }^{z}$ & $\mathrm{Yr}$ & Rates and adjuvants ${ }^{y}$ \\
\hline \multirow[t]{6}{*}{ Mesotrione } & HPPD & 2002 & $105 \mathrm{~g} \cdot \mathrm{ha}^{-1}$ a.i. $+1 \% \mathrm{COC}+2.5 \%$ UAN \\
\hline & & 2003 & $105 \mathrm{~g} \cdot \mathrm{ha}^{-1}$ a.i. $+1 \% \mathrm{COC}$ \\
\hline & & 2004 & $105 \mathrm{~g} \cdot \mathrm{ha}^{-1}$ a.i. $+1 \% \mathrm{COC}$ \\
\hline & & 2005 & $210 \mathrm{~g} \cdot \mathrm{ha}^{-1}$ a.i. $+1 \% \mathrm{COC}+2.5 \%$ UAN \\
\hline & & 2006 & $210 \mathrm{~g} \cdot \mathrm{ha}^{-1}$ a.i. $+1 \% \mathrm{COC}+2.5 \%$ UAN \\
\hline & & 2007 & $105 \mathrm{~g} \cdot \mathrm{ha}^{-1}$ a.i. $+1 \% \mathrm{COC}+3.6 \%$ UAN \\
\hline \multirow[t]{3}{*}{ Nicosulfuron } & ALS & 2003 & $35 \mathrm{~g} \cdot \mathrm{ha}^{-1}$ a.i. $+0.25 \%$ NIS $+2.5 \%$ UAN \\
\hline & & 2004 & $35 \mathrm{~g} \cdot \mathrm{ha}^{-1}$ a.i. $+0.25 \%$ NIS $+2.5 \%$ UAN \\
\hline & & 2006 & $70 \mathrm{~g} \cdot \mathrm{ha}^{-1}$ a.i. $+1 \% \mathrm{COC}+2.5 \% \mathrm{UAN}$ \\
\hline Foramsulfuron & ALS & 2004 & $37 \mathrm{~g} \cdot \mathrm{ha}^{-1}$ a.i. $+37 \mathrm{~g}$ isoxadifen-ethyl $\mathrm{ha}^{-1}+1 \% \mathrm{MSO}+2.5 \%$ UAN \\
\hline Tembotrione & HPPD & 2007 & $184 \mathrm{~g} \cdot \mathrm{ha}^{-1}$ a.i. $+92 \mathrm{~g}$ isoxadifen-ethyl $\mathrm{ha}^{-1}+1 \% \mathrm{COC}+2 \% \mathrm{UAN}$ \\
\hline Halosulfuron & ALS & 2002 & $36 \mathrm{~g} \cdot \mathrm{ha}^{-1}$ a.i. $+0.25 \% \mathrm{NIS}+2.5 \% \mathrm{UAN}$ \\
\hline Carfentrazone & $\mathrm{PPO}$ & 2002 & 9 g.ha ${ }^{-1}$ a.i. $+0.25 \%$ NIS \\
\hline
\end{tabular}

${ }^{\mathrm{z}} \mathrm{HPPD}=4$-hydroxyphenylpyruvate-dioxygenase inhibitor; ALS = acetolactate synthase inhibitor; PPO = protoporphyrinogen oxidase inhibitor.

${ }^{\mathrm{y}} \mathrm{COC}=$ crop oil concentrate; $\mathrm{MSO}=$ methylated seed oil; NIS $=$ nonionic surfactant; UAN $=28 \%$ urea ammonium nitrate. 
homozygous-tolerant hybrids, 24 to 45 heterozygous hybrids, and two to four homozygoussensitive hybrids were included in hybrid nurseries. Several hybrids were evaluated in more than 1 year such that the total number of observations of homozygous-tolerant, heterozygous, and homozygous-sensitive hybrids was 285, 199, and 20, respectively.

Among homozygous-sensitive hybrids, mean levels of injury after application of mesotrione ranged from $10 \%$ in $2003 \%$ to $86 \%$ in 2007 (Table 3). The lowest levels of injury within 1 week of treatment were in 2003 and 2005. These 2 years were characterized by both abnormally low rainfall preceding herbicide application and exceptionally cool (2003) or hot (2005) air temperatures the month herbicides were applied (Table 4). When heterozygous hybrids were injured $6 \%$ or greater, heterozygous hybrids were injured more severely than homozygous-tolerant hybrids, and homozygoussensitive hybrids were injured more than homozygous-tolerant or heterozygous hybrids. When data were pooled across years, mean injury from mesotrione application was different $(P<0.001)$ for each genotypic class, averaging $47 \%, 11 \%$, and $1 \%$ among homozygous-sensitive, heterozygous, and homozygous-tolerant hybrids, respectively (Fig. 1). Ninety-eight percent of 285 observations of homozygous-tolerant hybrids were $10 \%$ or less injured, whereas 17 of 20 observations of homozygous-sensitive hybrids were greater than $10 \%$ injured. Response of heterozygous hybrids was intermediate, with $52 \%$ of 199 observations having $10 \%$ or less injury and $48 \%$ having greater than $10 \%$ injury.

Injury from nicosulfuron application ranged from $0 \%$ to $90 \%$ (Table 5). When heterozygous hybrids were injured, injury was more severe than on homozygous-tolerant hybrids. Homozygous-sensitive hybrids were injured more severely than homozygoustolerant and heterozygous hybrids in all cases. Foramsulfuron application in 2004 resulted in the highest level of injury to homozygoustolerant hybrids $(16 \%)$. By 21 DAT with foramsulfuron, homozygous-sensitive hybrids were dead or nearly dead, whereas minimal injury ( $1 \%$ or less) to heterozygous and homozygous-tolerant hybrids was not significantly different.

Heterozygous and homozygous-tolerant hybrids were not injured by tembotrione; however, homozygous-sensitive hybrids were substantially injured (76\%) (Table 6). Injury from halosulfuron and carfentrazone was among the lowest observed in the hybrid nurseries, and only the homozygous-sensitive hybrids were significantly different among the three genotypic classes.

Mean levels of injury to heterozygous hybrids never exceeded injury to homozygous-sensitive hybrids nor did mean levels of injury to homozygous-tolerant hybrids exceed injury to heterozygous hybrids. Injury to homozygous-sensitive hybrids was significantly greater than injury to homozygoustolerant hybrids in all trials, representing six herbicides and three modes of action.
Table 2. Total number of hybrids in sweet corn hybrid nurseries and number of hybrids known to be homozygous or heterozygous for alleles conditioning tolerance or sensitivity to cytochrome P450metabolized herbicides.

\begin{tabular}{ccccc}
\hline & & \multicolumn{3}{c}{$\begin{array}{c}\text { Number of hybrids } \\
\text { with known herbicide } \\
\text { genotype }\end{array}$} \\
\cline { 3 - 5 } Year & $\mathrm{N}$ & Heterant & 24 & \\
\hline 2002 & 274 & 26 & 29 & 4 \\
2003 & 286 & 30 & 42 & 4 \\
2004 & 378 & 57 & 33 & 3 \\
2005 & 327 & 58 & 45 & 2 \\
2006 & 379 & 72 & 26 & 3 \\
2007 & 249 & 42 & 199 & 4 \\
& Total observations & 285 & 70 & 20 \\
& Total hybrids & 104 & & 9 \\
\hline
\end{tabular}

Table 3. Mean levels of injury on hybrids known to be homozygous or heterozygous for alleles conditioning tolerance or sensitivity after application of mesotrione in the sweet corn hybrid nurseries.

\begin{tabular}{|c|c|c|c|c|c|c|c|c|}
\hline & \multicolumn{2}{|c|}{2002} & \multirow{2}{*}{$\begin{array}{c}2003 \\
7 \mathrm{DAT}^{\mathrm{z}}\end{array}$} & \multicolumn{2}{|c|}{2004} & \multirow{2}{*}{$\begin{array}{c}2005 \\
7 \mathrm{DAT}^{\mathrm{z}}\end{array}$} & \multirow{2}{*}{$\begin{array}{c}2006 \\
7 \mathrm{DAT}^{\mathrm{z}}\end{array}$} & \multirow{2}{*}{$\begin{array}{c}2007 \\
7 \mathrm{DAT}^{\mathrm{z}}\end{array}$} \\
\hline & $\overline{7 \mathrm{DAT}^{2}}$ & $21 \mathrm{DAT}^{\mathrm{z}}$ & & $\overline{7 \text { DAT }^{2}}$ & $21 \mathrm{DAT}^{\mathrm{z}}$ & & & \\
\hline Genotypic class & \multicolumn{8}{|c|}{ - $\%$} \\
\hline Sensitive hybrids & $46 \mathrm{a}^{\mathrm{y}}$ & $25 \mathrm{a}$ & $10 \mathrm{a}$ & $46 \mathrm{a}$ & $13 \mathrm{a}$ & $14 \mathrm{a}$ & $73 \mathrm{a}$ & $86 \mathrm{a}$ \\
\hline Heterozygous hybrids & $16 \mathrm{~b}$ & $9 \mathrm{~b}$ & $8 \mathrm{~b}$ & $17 \mathrm{~b}$ & $1 \mathrm{~b}$ & $1 \mathrm{~b}$ & $13 \mathrm{~b}$ & $14 \mathrm{~b}$ \\
\hline Tolerant hybrids & $2 \mathrm{c}$ & $1 \mathrm{c}$ & $<1 \mathrm{c}$ & $3 \mathrm{c}$ & $0 \mathrm{~b}$ & $<1 \mathrm{~b}$ & $1 \mathrm{c}$ & $2 \mathrm{c}$ \\
\hline
\end{tabular}

${ }^{2}$ Percent injury (chlorosis) rated visually 7 or $21 \mathrm{~d}$ after treatment (DAT) with mesotrione.

${ }^{y}$ Means followed by the same letter are not significantly different as separated by Fisher's least significant difference $_{0.05}$.

Table 4. Departure from 30-year average precipitation and mean air temperature for the month of May and June in Urbana, $\mathrm{IL}^{\mathrm{z}}$.

\begin{tabular}{|c|c|c|c|c|}
\hline & \multicolumn{2}{|c|}{ May } & \multicolumn{2}{|c|}{ June } \\
\hline & $\begin{array}{c}\text { Temperature } \\
\text { departure }\end{array}$ & $\begin{array}{c}\text { Precipitation } \\
\text { departure }\end{array}$ & $\begin{array}{l}\text { Temperature } \\
\text { departure }\end{array}$ & $\begin{array}{c}\text { Precipitation } \\
\text { departure }\end{array}$ \\
\hline Year & - & 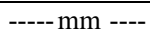 & - & --- mm - \\
\hline$\overline{2002}$ & -2.2 & +38 & +1.2 & -36 \\
\hline 2003 & -0.8 & -31 & -2.2 & -30 \\
\hline 2004 & +1.6 & -6 & -1.0 & -11 \\
\hline 2005 & -0.8 & -97 & +1.8 & -45 \\
\hline 2006 & -0.4 & -44 & -0.2 & -65 \\
\hline 2007 & +3.0 & -81 & +1.0 & +37 \\
\hline
\end{tabular}

${ }^{2}$ Based on data from a weather station within $1 \mathrm{~km}$ of experimental site (Illinois State Water Survey, Champaign, IL).

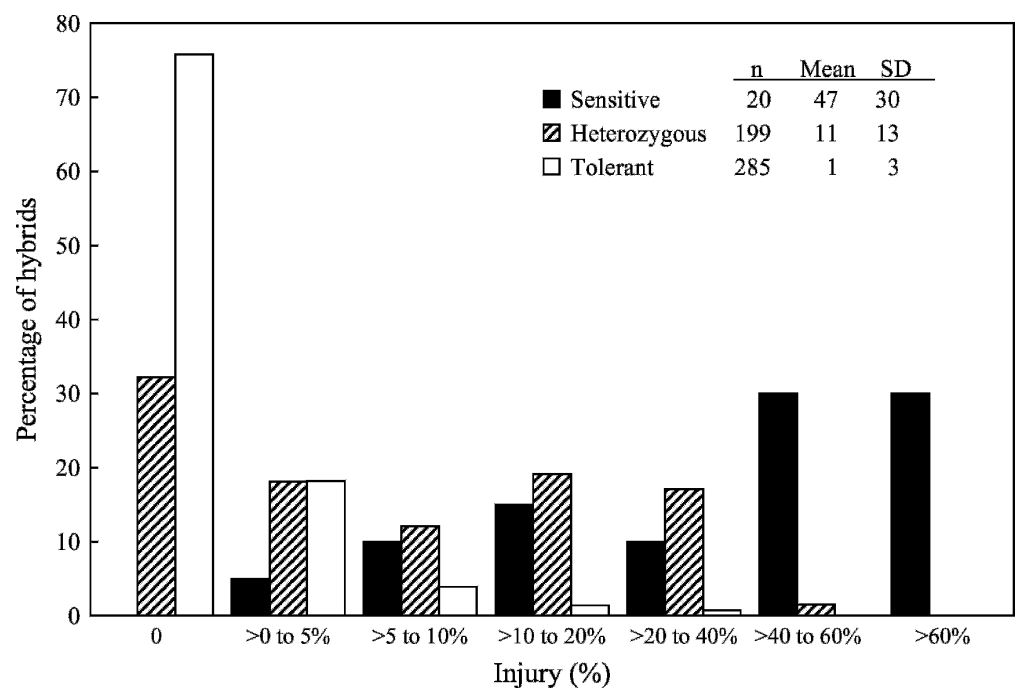

Fig. 1. Frequency distribution of levels of injury (chlorosis) from mesotrione observed in genotypes of hybrids at a locus conditioning herbicide sensitivity. Data from sweet corn hybrid nurseries from 2002 to 2007 and include 504 observations of 183 sweet corn hybrids. 
Table 5. Mean levels of injury on hybrids known to be homozygous or heterozygous for alleles conditioning tolerance or sensitivity after application of nicosulfuron or foramsulfuron in sweet corn hybrid nurseries.

\begin{tabular}{|c|c|c|c|c|c|c|c|}
\hline \multirow{4}{*}{$\begin{array}{l}\text { Genotypic } \\
\text { class }\end{array}$} & \multicolumn{5}{|c|}{ Nicosulfuron } & \multirow{2}{*}{\multicolumn{2}{|c|}{$\frac{\text { Foramsulfuron }}{2004}$}} \\
\hline & \multicolumn{2}{|c|}{2003} & \multicolumn{2}{|c|}{2004} & \multirow{2}{*}{$\begin{array}{c}2006 \\
14 \mathrm{DAT}^{\mathrm{z}}\end{array}$} & & \\
\hline & $\overline{7 \mathrm{DAT}^{\mathrm{z}}}$ & $21 \mathrm{DAT}^{\mathrm{z}}$ & $\overline{7 \mathrm{DAT}^{\mathrm{z}}}$ & $21 \mathrm{DAT}^{\mathrm{z}}$ & & $\overline{7 \mathrm{DAT}^{\mathrm{z}}}$ & $21 \mathrm{DAT}^{2}$ \\
\hline & -------. & ------ & ----- & $----\%$ & -------. & - & ------------ \\
\hline \multicolumn{8}{|l|}{ Sensitive } \\
\hline hybrids & $44 \mathrm{a}$ & $69 \mathrm{a}$ & $40 \mathrm{a}$ & $90 \mathrm{a}$ & $86 \mathrm{a}$ & $48 \mathrm{a}$ & $80 \mathrm{a}$ \\
\hline \multicolumn{8}{|l|}{ Heterozygous } \\
\hline hybrids & $10 \mathrm{~b}$ & $10 \mathrm{~b}$ & $21 \mathrm{~b}$ & $6 \mathrm{~b}$ & $0 \mathrm{~b}$ & $24 \mathrm{~b}$ & $1 \mathrm{~b}$ \\
\hline \multicolumn{8}{|l|}{ Tolerant } \\
\hline hybrids & $3 \mathrm{c}$ & $<1 \mathrm{c}$ & $8 \mathrm{c}$ & $0 \mathrm{c}$ & $0 \mathrm{~b}$ & $16 \mathrm{c}$ & $<1 \mathrm{~b}$ \\
\hline
\end{tabular}

zercent injury (whole-plant stunting and necrosis) rated visually 7, 14, or $21 \mathrm{~d}$ after treatment (DAT) with herbicides.

${ }^{\mathrm{y}}$ Means followed by the same letter are not significantly different as separated by Fisher's least significant difference $_{0.05}$.

Table 6. Mean levels of injury on hybrids known to be homozygous or heterozygous for alleles conditioning tolerance or sensitivity after application of tembotrione, carfentrazone, or halosulfuron in sweet corn hybrid nurseries.

\begin{tabular}{|c|c|c|c|c|c|}
\hline \multirow[b]{4}{*}{ Genotypic class } & \multirow{3}{*}{$\begin{array}{c}\text { Tembotrione } \\
2007 \\
7 \text { DAT }^{z}\end{array}$} & \multicolumn{2}{|c|}{ Halosulfuron } & \multicolumn{2}{|c|}{ Carfentrazone } \\
\hline & & \multicolumn{2}{|c|}{2002} & \multicolumn{2}{|c|}{2002} \\
\hline & & $7 \mathrm{DAT}^{\mathrm{z}}$ & $21 \mathrm{DAT}^{\mathrm{z}}$ & $7 \mathrm{DAT}^{\mathrm{z}}$ & $21 \mathrm{DAT}^{\mathrm{z}}$ \\
\hline & 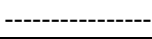 & ----- & $--\%$----- & $----\cdot$ & ------ \\
\hline Sensitive hybrids & $76 \mathrm{a}$ & $4 \mathrm{a}$ & $2 a$ & $4 \mathrm{a}$ & $2 a$ \\
\hline Heterozygous hybrids & $0 \mathrm{~b}$ & $<1 \mathrm{~b}$ & $<1 \mathrm{~b}$ & $<1 \mathrm{~b}$ & $<1 \mathrm{~b}$ \\
\hline Tolerant hybrids & $0 \mathrm{~b}$ & $<1 \mathrm{~b}$ & $<1 \mathrm{~b}$ & $0 \mathrm{~b}$ & $<1 \mathrm{~b}$ \\
\hline
\end{tabular}

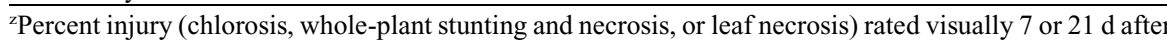
treatment (DAT) with herbicides.

${ }^{y}$ Means followed by the same letter are not significantly different as separated by Fisher's least significant difference $_{0.05}$.

Mean levels of injury to heterozygous hybrids was significantly greater than injury to homozygous-tolerant hybrids in 11 of 20 comparisons, the exception being when injury to heterozygous hybrids was $1 \%$ or less.

\section{Discussion}

Variation in levels of injury observed in sweet corn hybrid nurseries was associated with the genotypes of hybrids at a locusconditioning herbicide sensitivity, presumably the Nsf1 locus. Homozygous-tolerant hybrids were injured the least. Homozygoussensitive hybrids were injured the most. Injury to heterozygous hybrids was intermediate to the other two genotypic classes or similar to homozygous-tolerant hybrids. These results corroborate previous observations of variable responses of sweet corn hybrids to P450-metabolized herbicides. For example, Williams et al. (2005) observed an association between sweet corn responses to nicosulfuron and mesotrione now known to be the result of a common genetic basis (Nordby et al., 2008; Pataky et al., 2006b); however, the association was more evident among inbreds (homozygous for herbicide tolerance alleles) than hybrids (some of which were heterozygous). Williams et al. (2005) proposed that the lack of perfect association between hybrid responses to the two herbicides could have been the result of heterozygosity of genes affecting herbicide metabolism. In the present work, when heterozygous hybrids were injured (e.g., injury
$6 \%$ or greater), the level of injury exceeded that of homozygous-tolerant hybrids. If genes for herbicide tolerance are not completely dominant, which appears to be the case (Volenberg et al., 2006; Williams and Pataky, unpublished data), then heterozygous hybrids could have a slower rate of metabolic inactivation compared with homozygous-tolerant hybrids, resulting in greater levels of injury and more variable responses under different conditions.

Severity of crop injury is the result of a combination of genotypic and other factors affecting herbicide action. For instance, variability of hybrid response to mesotrione among the six hybrid nurseries, particularly for homozygous-sensitive hybrids, was likely the result of an influence of environmental factors. In general, conditions favoring plant growth improve uptake and translocation of foliar-applied herbicides. Soil moisture deficit and air temperature before herbicide application were among the most influential environmental variables on graminicide efficacy in 59 field experiments (Medd et al., 2001). The lowest levels of injury from mesotrione application in the present study were observed in years with abnormally dry conditions and unusually warm or cool temperatures, suggesting the low level of injury may have been the result of poor cuticular penetration and/or translocation of the herbicide. Most evaluations of sweet corn tolerance to nicosulfuron have resulted in a continuous range of responses (Morton and Harvey, 1992; O'Sullivan and Bouw, 1998; Robinson et al., 1993). Williams et al. (2005) hypothesized this range of responses could be the result of a combination of genetic and environmental factors affecting herbicide action. When homozygous-tolerant, heterozygous, and homozygous-sensitive sweet corn hybrids were evaluated for response to applications of nicosulfuron, mesotrione, and foramsulfuron in multiple locations, injury did not differ among genotypic classes when trial mean levels of injury were below $1 \%$ to $5 \%$ in trials located in dry climates, e.g., Idaho and Colorado (Pataky et al., 2008).

This study provides further evidence of a genetic basis for varied levels of injury to sweet corn hybrids from cytochrome P450metabolized herbicides. Overlap in crop response exists among genotypic classes (Fig. 1), suggesting that other genes and/ or environmental factors also influence crop injury. Nonetheless, the probability of injury from several P450-metabolized herbicides, including mesotrione, nicosulfuron, foramsulfuron, tembotrione, halosulfuron, and carfentrazone, is highest in homozygous-sensitive hybrids and least in homozygous-tolerant hybrids. Heterozygous hybrids appear to be most variable, having a response intermediate to the other two genotypic classes or similar to the homozygous-tolerant hybrids.

Enhancing cytochrome P450 activity may decrease the risk of crop injury in heterozygous hybrids. Two herbicides in these trials, foramsulfuron and tembotrione, were formulated with the safener isoxadifen-ethyl. By 21 DAT with foramsulfuron and 7 DAT with tembotrione, injury was $1 \%$ or less and similar between homozygous-tolerant and heterozygous hybrids (Tables 5 and 6). Williams and Pataky (2008) observed that four homozygous-sensitive hybrids were killed by application of tembotrione, but 22 heterozygous hybrids were not injured. They speculated that isoxadifen-ethyl reduced injury to the heterozygous hybrids by stimulating metabolism of the herbicide by cytochrome P450 enzymes, whereas the safener had little effect on homozygous-sensitive hybrids with two mutant CYP alleles. Bunting et al. (2004) found that isoxadifen-ethyl increased foramsulfuron absorption, translocation, metabolism, and crop tolerance of a hybrid injured by foramsulfuron alone. In dose-response studies, a heterozygous hybrid suffered up to $71 \%$ mean injury 7 DAT with tembotrione alone compared with only $9 \%$ mean injury when tembotrione was applied with isoxadifen-ethyl (Williams and Pataky, unpublished data). Thus, several new and emerging herbicide products formulated with P450-enhancing crop safeners such as isoxadifen-ethyl may reduce injury to heterozygous and homozygous-tolerant hybrids. Identifying sweet corn hybrids and inbred lines that carry mutant CYP alleles that condition herbicide sensitivity, and breeding with functional CYP genes into those hybrids and inbreds, also will reduce the frequency and severity of crop injury from several P450-metabolized herbicides. 


\section{Literature Cited}

Barrett, M., N. Polge, R. Baerg, R. Bradshaw, and C. Poneleit. 1997. Role of cytochrome P450 in herbicide metabolism and selectivity and multiple herbicide metabolizing cytochrome $\mathrm{P} 450$ activities in maize, p. 35-50. In: Hatzios, K. (ed.). Regulation of enzymatic systems detoxifying xenobiotics in plants. Kluwer Academic Publishers, Dordrecht, The Netherlands.

Bollman, J.D., C.M. Boerboom, D.W. Morishita, M.J. VanGessel, R.R. Bellinder, G.L. Jordan, and W. Cooley. 2005. Sweet corn hybrid tolerance to mesotrione, nicosulfuron, and foramsulfuron. North Central Weed Sci. Soc. Proceedings. 60:172.

Bradshaw, L.D., M. Barrett, and C.G. Poneleit. 1994. Inheritance of bentazon susceptibility in a corn (Zea mays) line. Weed Sci. 42:641-647.

Bunting, J.A., C.L. Sprague, and D.E. Riechers. 2004. Physiological basis for tolerance of corn hybrids to foramsulfuron. Weed Sci. 52:711-717.

Diebold, S., D. Robinson, J. Zandstra, J. O'Sullivan, and P.H. Sikkema. 2003. Sweet corn (Zea mays) cultivar sensitivity to AE F130360. Weed Technol. 17:127-132.

Fleming, A.A., P.A. Banks, and J.G. Legg. 1988. Differential responses of maize inbreds to bentazon and other herbicides. Can. J. Plant Sci. 68:501-507.

Kang, M.S. 1993. Inheritance of susceptibility to nicosulfuron herbicide in maize. J. Hered. 84:216-217.

Medd, R.W., R.J. Van De Ven, D.I. Pickering, and T. Nordblom. 2001. Determination of environmentspecific dose-response relationships for clodinafoppropargyl on Avena spp. Weed Res. 41: 351-368.

Morton, C.A. and R.G. Harvey. 1992. Sweet corn (Zea mays) hybrid tolerance to nicosulfuron. Weed Technol. 6:91-96.
Nordby, J.N., M.M. Williams II, J.K. Pataky, and D.E. Riechers. 2008. A common genetic basis in sweet corn inbred $\mathrm{Cr} 1$ for cross-sensitivity to multiple cytochrome P450-metabolized herbicides. Weed Sci. 56:376-382.

O'Sullivan, J. and W.J. Bouw. 1998. Sensitivity of processing sweet corn (Zea mays) cultivars to nicosulfuron/rimsulfuron. Can. J. Plant Sci. 78:151-154.

Pataky, J., M. Williams, P. Michener, J. Nordby, M. Bogner, R. Hasty, and C. Mapel. 2004. Sweet corn hybrid disease nursery-2004. Midwestern Vegetable Variety Trial Report for 2004. Purdue Agricultural Experiment Station Bulletin No. 2004-B17538. p. 94 118.

Pataky, J., M. Williams, B. Warsaw, M. Meyer, and J. Moody. 2006a. Sweet corn hybrid disease nursery-2006. Midwestern Vegetable Variety Trial Report for 2006, Purdue University, AES Bulletin No. B18048. p. 59-74.

Pataky, J., M. Williams, B. Warsaw, M. Meyer, and J. Moody. 2007. Sweet corn hybrid disease nursery-2007. Midwestern Vegetable Variety Trial Report for 2007, Purdue University, AES Bulletin No. B18246. p. 91-104.

Pataky, J., M.M. Williams II, J. Nordby, P. Michener, J. Frihauf, V. Castaneda, and A. Chavez. 2005. Sweet corn hybrid disease nursery-2005. Midwestern Vegetable Variety Trial Report for 2005. Purdue Agricultural Experiment Station Bulletin No. 2005B17810. p. 84-98.

Pataky, J.K., M.D. Meyer, J.D. Bollman, C.M Boerboom, and M.M. Williams II. 2008. Genetic basis for varied levels of injury to sweet corn hybrids from three cytochrome P450-metabolized herbicides. J. Amer. Soc. Hort. Sci. 133:438-447.

Pataky, J.K., P.M. Michener, A. Campana, T. Ledencan, and C. Sprague. 2003. Sweet corn hybrid disease nursery-2003. Midwestern Vegetable Variety Trial Report for 2003. Purdue Agricultural Experiment Station Bulletin No. 824. p. 67-81.

Pataky, J.K., P.M. Michener, A. Campana, and L. Wax. 2002. Sweet corn hybrid disease nursery-2002. Midwestern Vegetable Variety Trial Report for 2002. Purdue Agricultural Experiment Station Bulletin No. 818. p. 97111.

Pataky, J.K., J.N. Nordby, M.M. Williams II, and D.E. Riechers. 2006b. Inheritance of crosssensitivity in sweet corn to herbicides applied post emergence. J. Amer. Soc. Hort. Sci. 131:744-751.

Robinson, D.K., D.W. Monks, J.R. Schultheis, and A.D. Worsham. 1993. Sweet corn (Zea mays) cultivar tolerance to application timing of nicosulfuron. Weed Technol. 7:840-843.

Stall, W.M. and T.A. Bewick. 1992. Sweet corn cultivars respond differently to the herbicide nicosulfuron. HortScience 27:131-133.

Volenberg, D.S., M.M. Williams II, J.K. Pataky, and D.E. Riechers. 2006. Responses of tolerant and sensitive sweet corn inbreds and near isogenic hybrids to postemergence herbicides with different modes of action. North Central Weed Sci. Soc. Proceedings. 61:213.

Williams, M.M. II and J.K. Pataky. 2008. Genetic basis of sensitivity in sweet corn to tembotrione. Weed Sci. 56:364-370.

Williams, M.M. II, J.K. Pataky, J.N. Nordby, D.E. Riechers, C.L. Sprague, and J.B. Masiunas. 2005. Cross-sensitivity in sweet corn to nicosulfuron and mesotrione applied postemergence. HortScience 40:1801-1805.

Williams, M., S. Sowinski, T. Dam, and B.L. Li. 2006. Map-based cloning of the $n s f 1$ gene of maize. Program and Abstracts of the 48th Maize Genetics Conference, Pacific Grove, CA. 